NBER WORKING PAPER SERIES

\title{
THE MERITS OF HORIZONTAL VERSUS VERTICAL FDI IN THE PRESENCE OF UNCERTAINTY
}

\author{
Joshua Aizenman \\ Nancy Marion \\ Working Paper 8631 \\ http://www.nber.org/papers/w8631 \\ NATIONAL BUREAU OF ECONOMIC RESEARCH \\ 1050 Massachusetts Avenue \\ Cambridge, MA 02138 \\ December 2001
}

We thank Andy Bernard, Menzie Chinn, Michael Devereux, Mark Spiegel, Jaume Ventura, and the participants in the 4th International Economics Conference at UCSC [October 2001] for their helpful comments. The views expressed herein are those of the authors and not necessarily those of the National Bureau of Economic Research.

(C) 2001 by Joshua Aizenman and Nancy Marion. All rights reserved. Short sections of text, not to exceed two paragraphs, may be quoted without explicit permission provided that full credit, including (C) notice, is given to the source. 
The Merits of Horizontal versus Vertical FDI in the Presence of Uncertainty Joshua Aizenman and Nancy Marion

NBER Working Paper No. 8631

December 2001

JEL No. F21, F23

\begin{abstract}
This paper examines the impact of uncertainty on the profitability of vertical and horizontal foreign direct investment (FDI). Vertical FDI takes place when the multinational fragments the production process internationally, locating each stage of production in the country where it can be done at the least cost. Horizontal FDI occurs when the multinational undertakes the same production activities in multiple countries. We consider a model where the risk-neutral multinational must commit its investment prior to the realization of shocks. The multinational has monopoly power and confronts two types of risk. It may face random productivity shocks or encounter a host country that tries to confiscate its rents.

We show that greater uncertainty reduces the expected income from vertical FDI but increases the expected income from horizontal FDI. In addition, predatory actions by the host country are more costly to the multinational that has structured its production vertically rather than horizontally. Consequently, increased uncertainty should encourage horizontal FDI but discourage vertical FDI. If vertical FDI is more likely to flow into emerging markets and horizontal FDI into mature markets, then the empirical finding that most FDI is horizontal rather than vertical might be due, in part, to the greater uncertainty associated with emerging markets.

We report cross-country regression results that provide some support for the predictions of the model. Volatility appears to have a differential impact on FDI inflows into mature and emerging markets. For mature markets that supposedly attract mainly horizontal FDI, greater volatility significantly increases FDI inflows. For emerging markets that receive relatively more vertical FDI inflows, increased volatility does not increase FDI inflows.
\end{abstract}

Joshua Aizenman

Department of Economics

University of California, Santa Cruz

Santa Cruz, CA 95064

and NBER

jaizen@cats.ucsd.edu

$831-459-4791$
Nancy Marion

Department of Economics

Dartmouth College

Hanover, NH 03755

nancy.marion@dartmouth.edu

603-646-2511 


\section{Introduction}

The tremendous growth of foreign direct investment (FDI) over the last decade has received considerable attention. Markusen and Maskus (2001) survey recent studies of FDI that adopt a general-equilibrium trade-theoretic view of the multinational. They also provide a useful overview of a model where firms choose endogenously between vertical and horizontal production structures when investing abroad. A vertical pattern arises when the multinational firm fragments the production process internationally, locating each stage of production in the country where it can be done at the least cost. A horizontal pattern occurs when the multinational produces the same product or service in multiple countries.

Markusen and Maskus note that the choice between vertical and horizontal production structures depends on country characteristics, such as relative size and relative endowment differences, as well as trade and investment costs. ${ }^{1}$ Their review of recent

\footnotetext{
${ }^{1}$ When the industrial-organization approach to trade was first applied to the multinational, researchers developed separate vertical and horizontal models to describe firm behavior. See Helpman (1984) and Helpman and Krugman (1985) for examples where vertical models were used; see Markusen (1984), Markusen and Horstman (1987) and Brainard (1997) for examples where horizontal ones were employed. Eventually, the two approaches were integrated in a "knowledge-capital model." Markusen and Maskus (2001) describe this integrated approach and highlight its three assumptions about technology:

(a) The location of knowledge-based assets may be fragmented from production;

(b) Knowledge-based assets are skilled-labor intensive relative to final production; and

(c) The services of knowledge-based assets are joint inputs into multiple production facilities.
}

Properties (a) and (b) motivate vertical multinationals, whereas (c) gives rise to horizontal patterns. See Carr, Markusen and Maskus (2001) for an empirical test of the knowledgecapital model. 
empirical work leads them to conclude that most FDI is of the horizontal type. Since horizontal FDI is most prevalent among countries that are similar in both size and in relative endowments, they argue that "it is similarities between countries rather than differences that generate the most multinational activities." (Markusen and Maskus, 2001, p. 39)

Most of the trade-theoretic FDI literature [including the papers reviewed by Markusen and Maskus (2001)] relies on non-stochastic models. ${ }^{2}$ The purpose of this paper is to investigate the role of uncertainty on the relative profitability of horizontal versus vertical production modes. Focusing on uncertainty is important because emerging markets are characterized by much greater uncertainty than the OECD countries. ${ }^{3}$ They are also the potential recipients of most vertical FDI since their relative factor endowments and other features differ from those of mature economies where parent firms are based. If greater uncertainty discourages vertical FDI, the observed lack of vertical FDI might be the result of greater uncertainty associated with emerging markets rather than just the weakness of forces encouraging geographic fragmentation of production. Further, a reduction in the uncertainty

\footnotetext{
${ }^{2}$ See Dunning (1993) for a good overview of the earlier literature. There are a few papers that examine FDI in a stochastic setting. For example, Aizenman (1994) studies the effects of exchange-rate volatility on horizontal FDI. Spiegel (1994) examines the impact of sovereign risk on FDI inflows relative to portfolio investment. Goldberg and Kolstad (1995) study the effects of real exchange-rate uncertainty on FDI under risk aversion and use U.S. bilateral FDI flows to confirm their prediction that higher real exchange rate volatility increases FDI. Wei (1997) identifies the adverse effects of corruption-induced uncertainty on FDI.
}

${ }^{3}$ See Hausmann and Gavin (1995). 
faced by multinationals engaged in FDI should increase the incidence of vertical investments in emerging markets.

The pattern of FDI between the U.S. and Mexico illustrates the issues involved. As NAFTA increases the economic integration and the mutual dependency of its members, it may also reduce the sovereign risk associated with investment in Mexico and contribute to the observed increase in vertical FDI there. ${ }^{4}$ Hence, previous findings reporting the dominance of horizontal FDI may understate the potential scope for vertical FDI. ${ }^{5}$

Understanding the determinants of vertical and horizontal FDI is also important since these two production strategies can have very different implications for the distribution of income both within and across countries. Vertical FDI may compress the skilled-nonskilled wage differential across countries as well as change the income distribution within countries. Horizontal FDI may increase income in each country with minor distributive impact.

In order to explore the role of uncertainty on vertical and horizontal FDI, we develop a model where the multinational making investment decisions faces productivity shocks. These shocks increase the expected profits of horizontal FDI because the multinational has the incentive to reallocate production and employment from less productive plants to more productive ones, even if it is risk neutral. In contrast, productivity shocks reduce the expected profits from vertical FDI since, with limited substitutability, low realized productivity in a plant that is part of a vertical chain increases the demand for labor in that

\footnotetext{
4In fact, the formation of NAFTA has affected many determinants of FDI. See Feenstra and Hanson (1997) for a detailed analysis of the impact of NAFTA on FDI and relative wages.
}

5 Hanson, Mataloni and Slaugher (2001) argue that vertical FDI is more common than previous research suggested. 
plant in order to compensate for the productivity shortfall. Had the plant been part of a horizontal structure, it would have experienced a fall in the demand for labor as output shifted to more productive plants.

Horizontal production also entails lower exposure to sovereign risk than does a vertical production structure. Suppose that the host country reverses its attitude towards multinationals and tries to force the multinational to renegotiate rents by threatening nationalization, production disruptions or similar actions. We show that limited substitutability across geographically-separated production stages under a vertical structure grants more bargaining clout to the host country than if the FDI had been horizontal in nature. Hence, predatory behavior by the host country is more costly to the multinational engaged in vertical FDI. ${ }^{6}$

Finally, we undertake a cross-country regression analysis to determine the extent of support for the predictions of the model. We examine the partial correlation between some uncertainty measures and net FDI to countries with different relative incomes while controlling for additional relevant variables. When uncertainty is measured by real effective exchange-rate volatility, the correlation between volatility and FDI inflows is significantly different for mature and emerging markets. The correlation between exchange-rate volatility and FDI inflows is positive and significant for relatively high-income countries. For lower-income

${ }^{6} \mathrm{We}$ assume that the multinational faces only two options- vertical and horizontal investment. This imposed limitation on the firm's choice set might arise from its desire to control the use of knowledge-capital or because of contracting and enforcement problems. Our analysis thus sidesteps some important elements of firm organization. See Grossman and Helpman (2001) for a model of the endogenous organization of the firm in the open economy. 
countries, the correlation is not negative, but it is insignificantly different from zero. This finding is consistent with the view that greater uncertainty discourages vertical FDI and emerging markets attract a relatively greater share of vertical FDI.

The rest of the paper is organized as follows. Section 2 lays out the stochastic model, specifying the two feasible modes of FDI- horizontal and vertical. Section 3 examines the impact of productivity shocks on the profits of each type of FDI. Section 4 evaluates the impact of sovereign risk on profits when the host country has bargaining power. Section 5 examines some empirical evidence in support of the view that greater uncertainty has a differential impact on horizontal and vertical FDI. Section 6 concludes.

\section{The Model}

We consider a global economy composed of 2 countries, $\mathrm{H}$ and $\mathrm{F}$, each consuming two final goods, $Y$ and $Z$. Asterisks signify foreign (country F) variables. The utility of $\mathrm{H}$ consumers is a semi-additive function of the two goods

$$
U=Z+\frac{A}{\delta}[Y]^{\delta}, \quad 0<\delta<1
$$

Similar preferences characterize consumers in country F.

The supply of labor in each country is inelastic and given by

$$
L^{s}=\bar{L} ; \quad L^{s^{*}}=\bar{L}^{*}
$$

Good $Z$ is produced in both countries using a simple Ricardian technology. In $\mathrm{H}$, this technology is

$$
Z=L_{z}
$$

so the real wage is one in the competitive equilibrium. We normalize the price of good $Z$ to one. 
In country $\mathrm{F}$, the technology is:

$$
Z^{*}=a^{*} L_{z}^{*},
$$

where the parameter $a^{*}$ is the productivity of foreign labor and the real wage is $w^{*}=a^{*}$.

Good $Y$ is produced by a monopoly using two possible production modes: vertical or horizontal.

\section{Vertical Production of Good Y}

The vertical mode implies that production is fragmented geographically. Suppose the final production stage uses intermediate inputs produced abroad at an earlier stage.

Specifically, assume that an intermediate input, $M$, is produced in the foreign country using a Cobb-Douglas production technology

$$
M=\left(1+\varepsilon^{*}\right) b^{*} \sqrt{L_{M}^{*}}
$$

where $L_{M}^{*}$ is the labor employed, $b^{*}$ is labor productivity in the foreign intermediate-good sector, and $\varepsilon^{*}$ is a mean zero foreign productivity shock that is uncorrelated with any domestic shock. The final production stage combines intermediate input $M$ and domestic labor using a Leontief technology to produce $Y^{f}$, where

$$
Y^{f}=\operatorname{Min}\left[M ;(1+\varepsilon) b \sqrt{L_{Y}}\right] ; \quad E(\varepsilon)=0, \operatorname{cov}\left(\varepsilon \varepsilon^{*}\right)=0
$$

The fragmented production process requires the multinational to invest in two plants, resulting in a total set-up cost of $C_{f}$. 


\section{$\underline{\text { Horizontal Production of Good Y }}$}

Alternatively, the multinational can follow a horizontal strategy, producing $Y$ in both markets according to the following technology

$$
Y=(1+\varepsilon) a \sqrt{L_{Y}} ; \quad Y^{*}=\left(1+\varepsilon^{*}\right) a \sqrt{L_{Y}^{*}} .
$$

where $L_{Y}\left(L_{Y}^{*}\right)$ is the labor employed in producing good $\mathrm{Y}$ in country $\mathrm{H}(\mathrm{F})$, and $\varepsilon, \varepsilon^{*}$ are uncorrelated productivity shocks with zero means. The horizontal production process also requires the multinational to invest in two plants, resulting in a total set-up cost of $C_{h}$.

In order to focus on the impact of uncertainty, we assume zero transportation costs. Hence, proximity to the consumer does not play a role in determining production patterns. ${ }^{7}$ The main differences between vertical and the horizontal production strategies lie in the time sequencing and the substitutability. With horizontal production, global demand is met by production in both countries. The various plants produce perfect substitutes. With vertical production, the intermediate good is produced before the final good. There is very limited substitutability between the outputs produced in the various production stages.

The monopoly must pre-commit to a horizontal or vertical investment strategy prior to the realization of shocks. The monopoly is risk neutral and chooses the production strategy that maximizes its expected profit.

\footnotetext{
7 Note that if markets are segmented, horizontal FDI will be motivated by tariff jumping, and the volatility of domestic demand will become important. Along with most of the recent literature, we ignore this channel because of the large decline in effective protection in recent years.
} 
We now calculate the expected profit of vertical and horizontal investments. From

(1), we observe that the demand elasticity for good $\mathrm{Y}$ faced by the monopoly is $\eta=\frac{1}{1-\delta}$. In the Appendix, we show that the expected profit associated with vertical production is

$$
E\left[\Pi_{f}\right]=k_{f} E\left\{\left[\theta_{f}(1+\varepsilon)^{-2}+\theta_{f}^{*}\left(1+\varepsilon^{*}\right)^{-2}\right]^{-\frac{\eta-1}{\eta+1}}\right\}-C_{f}
$$

where $k_{f} ; \theta_{f} ; \theta_{f}^{*}$ are constants and $\theta_{f}+\theta_{f}^{*}=1$. The weights $\theta_{f} ; \theta_{f}^{*}$ reflect the effective productivities of the two countries and are determined by real wages and the productivity coefficients $b, b^{*} .8$

The expected profit associated with horizontal production is

$$
E\left[\Pi_{h}\right]=k_{h} E\left\{\left[\theta_{h}(1+\varepsilon)^{2}+\theta_{h}^{*}\left(1+\varepsilon^{*}\right)^{2}\right]^{\frac{\eta-1}{n+1}}\right\}-C_{h} ;
$$

where $k_{h} ; \theta_{h} ; \theta_{h}^{*}$; are constants and $\theta_{h}+\theta_{h}^{*}=1$. The weights $\theta_{h} ; \theta_{h}^{*}$ reflect the effective productivities of the two countries and are now determined by real wages and the

\footnotetext{
${ }^{8}$ Equation (8) assumes that the production of $M$ takes place after the realizations of productivity shocks in both locations. If the production of $M$ takes place before the realization of the domestic productivity shock, the expected profit is
} $E\left[\Pi_{f}\right]=k_{f} E\left\{\left[E\left[\theta_{f}(1+\varepsilon)^{-2}\right]+\theta_{f}^{*}\left(1+\varepsilon^{*}\right)^{-2}\right]^{-\frac{\eta-1}{\eta+1}}\right\}-C_{f}$. The main results hold for either scenario. 
productivity coefficients, $a, a^{*}$. We assume that fixed costs $C_{h} ; C_{f}$; are large enough so that it is never profitable to set up more than two plants. ${ }^{9}$

\section{Profitability in the face of productivity shocks}

We now compare the effects of stochastic productivity changes on expected profits from horizontal and vertical investment strategies. The outcome will depend on the concavity/convexity of the profit functions specified in (8) and (9). In the Appendix we show that

Proposition 1: Higher volatility of shocks increases the expected profit associated with horizontal FDI but reduces the expected profit associated with vertical FDI.

Suppose that the multinational is indifferent between the two production modes in the absence of uncertainty. Proposition 1 implies that uncertainty will bias production patterns towards horizontal FDI. The reason is that volatility induces the multinational engaged in horizontal FDI to reallocate production and employment from less productive plants to more productive ones. Such behavior is optimal even if the multinational is risk neutral. This reallocation increases the expected profit of horizontal FDI. With vertical FDI, there is more limited substitutability among outputs, so a low realized productivity in

\footnotetext{
${ }^{9}$ This assumption allows us to exclude mixed horizontal and vertical production patterns [such as the case where $M$ is produced in both countries and the final good is produced at home]. In practice, if there are a large number of countries and the fixed costs are not prohibitive, mixed production modes may be useful in diversifying country-specific risk or reducing the incidence of predatory behavior.
} 
one plant actually increases the demand for labor in that plant in order to compensate for the productivity shortfall. Consequently, more volatile shocks reduce the expected profit of vertical FDI.

The first-order conditions that give the optimal employment allocation under uncertainty for each type of investment strategy illustrate the point:
a. Vertical$$
\frac{L_{Y}}{L_{M}^{*}}=\frac{\left[b^{*}\left(1+\varepsilon^{*}\right)\right]^{2}}{[b(1+\varepsilon)]^{2}}
$$
b. Horizontal

$$
\frac{L_{Y}}{L_{Y}^{*}}=\frac{[a(1+\varepsilon)]^{2}}{\left[a^{*}\left(1+\varepsilon^{*}\right) / w^{*}\right]^{2}}
$$

Inspection of (10) reveals that the employment responses to increased uncertainty are completely opposite for the two modes of production. The different employment responses lead directly to the different profitability outcomes.

A graphical illustration of these results is provided in Figure 1. Panel 1a plots the marginal product of labor $\left(\mathrm{MP}_{\mathrm{L}}\right)$ in a plant in country $\mathrm{F}$ that is part of a vertical production process. The plant produces intermediate input $M$. In the absence of uncertainty the plant produces $M_{o}$ of the intermediate input, which, in turn, supports the production of final output $Y_{o} ; Y_{o}=M_{o}$. [see equation (6)]. Suppose now that productivity in F fluctuates between $\left(1+\varepsilon_{0}^{*} ; 1-\varepsilon_{0}^{*}\right)$ with equal probability. In order to keep producing $M_{o}$ to maintain final output $Y_{o}$, employment must fluctuate between $L_{h}^{*}$ and $L_{l}^{*}$. The needed increase in 
employment in the bad state of nature exceeds the drop in employment in the good state of nature by a significant margin. This follows because the two bold trapezoids have the same area [i.e., area $\mathrm{E}$ equals areas $\mathrm{D}+2 \mathrm{C}] .{ }^{10}$ Consequently, higher volatility increases the expected employment per unit output in a vertical production mode, increasing expected unit cost and reducing expected profits.

Panel $1 \mathrm{~b}$ plots the $\mathrm{MP}_{\mathrm{L}}$ in a plant in country $\mathrm{F}$ that is part of a horizontal production process. The multinational allocates production so that marginal cost is the same in all plants. [See the Appendix for further details.] Suppose that in the absence of uncertainty employment is $L_{0}^{*}$. Now let productivity in F fluctuates between $\left(1+\varepsilon_{0}^{*} ; 1-\varepsilon_{0}^{*}\right)$ with equal probability. At a given marginal cost, employment in the plant in country F will fluctuate between $L_{h}^{*}$ and $L_{l}^{*}$. It is easy to verify that, in these circumstances, greater volatility increases expected output by the shaded triangle, while expected employment in plant $\mathrm{F}$ remains at $L_{0}^{*}$. Consequently, greater volatility induces a reallocation of employment towards the more productive plant, increasing expected output per worker at a given marginal cost of production and also expected profits. ${ }^{11}$

\footnotetext{
${ }^{10}$ Note that the area under the marginal product curve equals output. The figure is drawn for the case where employment adjusts to keep output at level $M_{o}$ in each state of nature. Consequently, $\mathrm{E}=\mathrm{B}+\mathrm{C}$ and $\mathrm{A}=\mathrm{C}+\mathrm{D}$. Note also that $\mathrm{A}=\mathrm{B}$ [At a given employment, the upward shift in the MP curve in the good state of nature, equal to $\varepsilon_{0}^{*} M P^{*}$, is the same as the downward shift in the MP curve in the bad state of nature.]. Combining the above equations, we infer $\mathrm{E}=\mathrm{D}+2 \mathrm{C}$.
}

11 While the comparative statics and simulations reported in the paper are general equilibrium in nature, taking into account relative price effects, the graphical interpretation 
Figure 2 reports a simulation for the case where the home economy is stable but foreign productivity fluctuates between $\left(\varepsilon_{0}^{*},-\varepsilon_{0}^{*}\right)$, with equal probabilities. The simulation corresponds to the case where the multinational is indifferent between horizontal and vertical FDI in the absence of uncertainty and where set-up costs for the two production strategies are identical. The simulation reports the dependence of the expected gross profits [before netting out the set-up costs] on $\varepsilon_{0}^{*}$ when gross profits in the absence of uncertainty are normalized to 1 and $\eta=4$. The bold (dotted) line corresponds to horizontal (vertical) FDI. When $\varepsilon_{0}^{*}=0.5$, expected profits are about $15 \%$ higher under horizontal FDI.

\section{Exposure to sovereign risk and the pattern of production}

Over the last twenty years, FDI has been subject to few nationalizations or other predatory interventions by sovereign states. Nevertheless, the risk of confiscation remains. It can be shown that a multinational engaged in vertical FDI is exposed to higher sovereign risk than one involved in horizontal FDI. To simplify the argument, we keep all our previous assumptions and focus on the case where productivity is certain (hence $\varepsilon=\varepsilon^{*}=0$ ).

Suppose that the host country forces a new division of the surplus associated with FDI by threatening to stop production in the absence of agreement. We use the Nash bargaining solution to infer the outcome for the case where both parties have equal bargaining power.

described above relies on partial-equilibrium analysis. As a simplification, the graphs are drawn for a given relative price of $Y$, so it is assumed the shocks do not impact the equilibrium marginal cost. 
In the absence of agreement, the gross profit of the multinational engaged in vertical FDI is zero. (We assume the host country's income is not affected by the absence of agreement.) Since the symmetric Nash bargaining solution requires a division of the surplus that maximizes the product of the gains from the agreement, it follows that bargaining leads to an equal division of the gross profits $\left(k_{f}\right)$ between the host country and the multinational. Hence, the multinational's net profit in the bargaining regime is

$$
0.5 k_{f}-C_{f}
$$

[See the Appendix for details.] In this case, a switch to the bargaining outcome when FDI is vertically structured reduces the multinational's gross profit by $50 \%$.

With horizontal FDI, the perfect substitutability of outputs produced in the two countries reduces the bargaining clout of the host country. In the Appendix we show that a switch to the bargaining outcome reduces profit from horizontal FDI by :

$$
0.5\left(1-\left\{\theta_{h}\right\}^{2 \frac{\eta-1}{\eta+1}}\right)
$$

Figure 3 plots the percentage loss in gross profit as a function of the elasticity of demand. The figure illustrates the loss for the case where production shares in the two countries are identical, $\theta_{d}=\theta_{d}^{*}$. Recall that with vertical FDI, the multinational lost $50 \%$ of its gross profit following the switch to the bargaining regime. The ability to diversity production when FDI is horizontal cuts the exposure to the political risk induced by the threat of nationalization or production stoppage. 


\section{Empirical Evidence}

We now muster some suggestive evidence that increased uncertainty encourages horizontal FDI but discourages vertical FDI. Because foreign direct investment data do not distinguish between horizontal and vertical patterns, we draw on earlier work suggesting most horizontal FDI takes place between similar countries while most vertical FDI occurs between dissimilar ones. Since multinationals are generally headquartered in mature economies, we shall assume FDI inflows into mature markets are primarily horizontal while FDI inflows into emerging markets have a relatively larger vertical component. We therefore wish to discover whether greater uncertainty increases FDI inflows into mature markets but reduces inflows into emerging markets.

Our approach is to examine the partial correlation between various uncertainty measures and net FDI inflows for mature and emerging markets while controlling for additional relevant variables. While both macroeconomic and microeconomic approaches offer important insights into the measurement of FDI and the appropriate controls, in this paper we focus on a macro approach. ${ }^{12}$

We conduct a cross-section analysis with a sample of 103 countries chosen on the basis of data availability. The complete list of countries is found in the Appendix. Rather than identify mature and emerging markets according to an arbitrary classification scheme, we use a more flexible categorization based on relative income. Let $\mathrm{z}$ be defined as a country's real

\footnotetext{
${ }^{12}$ For examples of micro-oriented estimates of FDI, see Carr, Markusen and Maskus (2001), Smarzynska and Wei (2000) and Blonigen (1997). They typically use firm-level bilateral data to construct a measure of FDI. Our approach follows studies that apply a macrooriented methodology to private investment and growth. See, for example, Aizenman and Marion (1993, 1999) and Ramey and Ramey (1995).
} 
GDP per capita, measured on a purchasing power parity basis, relative to the richest country in the sample, the United States. Thus $0<z \leq 1$. We interact linear and quadratic values of $\mathrm{z}$ with our volatility measure in order to test whether volatility has a larger impact on FDI inflows for countries with relatively higher incomes.

The average $\mathrm{z}$ value for our sample of 103 countries is 0.2867 . The minimum value of $\mathrm{z}$ is 0.0298 while the maximum value is, of course, one. In order to identify the relevant range of $\mathrm{z}$ values for mature markets, we compute $\mathrm{z}$ values for the 21 countries in the sample that are OECD members and are classified as industrial by the International Monetary Fund's

International Financial Statistics (2001). The average $\mathrm{z}$ value for this group is 0.70 and ranges from a low of 0.325 to a high of one. In order to identify the relevant range of $z$ values for emerging markets, we compute $\mathrm{z}$ values for 24 countries identified as emerging markets by the International Finance Corporation (1999). Our emerging-market group includes non-industrial OECD members, such as Turkey, Mexico, and South Korea, as well as commonly identified non-OECD emerging markets, such as Argentina, Brazil and Thailand. The group's average $\mathrm{z}$ value is 0.2073 , with a low of 0.0576 and a high of 0.5151 .

Our FDI data come from the World Bank's World Development Indicators. The data measure net FDI inflows into a country as a share of its GDP. We use these data to construct for each country the average net FDI inflow over the 1980-99 period. The average inflow over this twenty-year period is our dependent variable in the cross-section regression. In our sample, the mean value of FDI inflows as a share of GDP is 1.64 percent; its maximum value is just under 10 percent. Among the mature economies, FDI/GDP ranges between 0.04\% (Japan) and $3.9 \%$ (Belgium), with an average value of $1.6 \%$. For the emerging markets, FDI/GDP ranges between $0.21 \%$ (India) and $5.04 \%$ (Hungary), with an average value of $1.58 \%$. 
Our choice of controls is influenced by the ones identified in Levine and Renelt (1992) as important for cross-country domestic investment and growth equations. We use the following control variables for each country: (1) the initial log level of real GDP per capita and its squared value, (2) the initial secondary school enrollment rate, (3) the initial growth rate of the population, and (4) the average share of trade (exports plus imports) in GDP over the period.

To measure uncertainty, we consider both the volatility of output and the volatility of the real effective exchange rate. It may be argued that real exchange-rate volatility is part of a reduced-form measure of the output volatility described in the model. We construct our output volatility measure by taking the standard deviation of the innovation from a first-order autoregressive output process based on annual real GDP data over the 1980-1999 period. We construct our exchange-rate volatility measure by taking the standard deviation from the average monthly percentage change in the real effective exchange rate over the same twentyyear period. ${ }^{13}$ In the sample, output volatility in emerging markets is double what it is in mature markets. Real effective exchange-rate volatility is about three times higher in emerging markets.

We first examine the effects of output volatility on FDI inflows, taking into account a country's relative income position. Regression (1) in Table 1 displays the results. The

${ }^{13}$ The volatility variable is a generated regressor. See Pagan (1984) for a discussion of the econometric issues related to generated regressors. If rational agents form their expectations about volatility according to the processes we specify, then there is no errors-in-variables problem and the standard errors of the coefficients attached to the volatility measures are consistent once they are corrected for heteroscedasticity. 
marginal effect of volatility on FDI inflows is $\hat{\beta}_{1}+\hat{\beta}_{2} z+\hat{\beta}_{3} z^{2}$, where the $\hat{\beta}_{i}(\mathrm{i}=1,2,3)$ are the estimated coefficients on volatility, (volatility*z), and (volatility* $z^{2}$ ), respectively. If increased volatility encourages horizontal FDI but discourages vertical FDI, we would expect to find a positive marginal effect for relatively high values of $\mathrm{z}$ associated with mature markets that attract mainly horizontal FDI. We would also expect to uncover a negative marginal effect for low values of $\mathrm{z}$ tied to emerging markets that attract relative more vertical FDI. The results for output volatility are disappointing. The correlation between output volatility and FDI inflows is insignificantly different from zero regardless of the relative income position of the country.

The results for exchange-rate volatility are more promising. Regression (2) in Table 1 reports the cross-section estimation results when uncertainty is measured by real effective exchange-rate volatility. We find that volatility has a positive impact on FDI inflows. Moreover, the size and significance of this impact increase as the recipient's relative income rises. Figure 4 illustrates the correlation between exchange-rate volatility and FDI inflows for different relative income positions. ${ }^{14}$

When $\mathrm{z}$ is in the upper range associated with mature markets, we observe that volatility is positively and significantly correlated with FDI inflows. For instance, when $\mathrm{z}$ is 0.70 , the average value for the mature economies in our sample, the marginal effect of volatility on FDI inflows is 86.6653 and its standard error is 27.7582 . With FDI inflows and volatility at their average values initially, a $10 \%$ increase in volatility increases the share of FDI inflows in GDP by $7.5 \%$ in the typical mature economy. This type of response to volatility is just what we would expect if mature markets attract mostly horizontal FDI.

14 The marginal effect of exchange-rate volatility becomes significantly different from zero when $0.263<\mathrm{z}<0.264$. 
When $\mathrm{z}$ is in the lower range associated with emerging markets, volatility has a much smaller positive effect on FDI inflows. When $\mathrm{z}$ is 0.207 , the average $\mathrm{z}$ value for the IFCidentified emerging markets, the marginal effect of volatility on FDI inflows is 5.1876 and its standard error is 3.0168. The effect is not significantly different from zero at the 95 percent confidence level.

The finding that output volatility is not significantly correlated with FDI inflows, whereas real effective exchange-rate volatility is significantly correlated with FDI inflows to high-income countries, can be rationalized in several ways. First, if most of the shocks contributing to output volatility originate in the non-traded goods sector, output volatility may have little impact on FDI whereas exchange-rate volatility impacts multinationals directly. Second, one expects output shocks to be positively correlated across countries but real effective exchange-rate shocks to be negatively correlated. Consequently, exchange-rate volatility may matter more than output volatility for the location decisions of multinationals. ${ }^{15}$

Our theory predicts that greater volatility should reduce FDI inflows to countries that attract mainly vertical FDI. ${ }^{16}$ Our finding that volatility has an insignificant effect on FDI inflows into emerging markets is consistent with the theory if emerging markets attract a mix of vertical and horizontal FDI, though a relatively greater share of vertical FDI. Alternatively, if

15 Our output volatility measure may also be less precisely measured. Since the Penn World Tables have PPP-adjusted real GDP data only for the period 1980-1992, we calculated our output volatility measure using non-PPP-adjusted real GDP data over the 1980-1999 period.

${ }^{16} \mathrm{It}$ is worth noting that a significant negative correlation has been uncovered between various volatility measures and domestic private investment in developing countries. See Aizenman and Marion (1999). 
emerging markets do attract mostly vertical FDI, but horizontal FDI is much more responsive to increased volatility than vertical FDI, then increased volatility could have a negligible effect on aggregate FDI inflows.

There are probably additional factors at work. For example, it may be the case that greater volatility actually reduces FDI inflows into emerging markets but also adversely affects GDP, so that we pick up a small positive effect of volatility on FDI inflows scaled by GDP. ${ }^{17}$ It could also be the case that our volatility measures imperfectly capture the uncertainty facing multinationals, and that a broader, or different, measure of volatility might uncover a negative correlation. Another possibility is that the real exchange-rate volatility measure generates relative wealth effects across firms in various countries, with wealthier multinationals increasing both their vertical and horizontal FDI. ${ }^{18}$

The lack of a significant correlation between volatility and FDI inflows for countries whose relative income position is comparable to our emerging market group might also be the outcome of including some countries with such limited FDI that volatility has no distinguishable effect on their inflows. For example, some countries may have such poor fundamentals that they attract little or no FDI. Countries with low per capita GDP may have inadequate infrastructure (e.g., ports, roads, communication facilities) to attract FDI. They might have a lot of political instability or corruption that discourages FDI inflows.

17 Instead of scaling FDI inflows by GDP, we also tried using the log of real FDI inflows over the 1980-1999 period as our dependent variable. In that case, exchange-rate volatility did have a negative effect on FDI to emerging markets, but the effect was still not significantly different from zero.

18 See Froot and Stein (1991) and Klein and Rosengren (1994) for a discussion of real exchange rates, relative wealth effects and U.S. inward FDI. 
We let real GDP per capita proxy for the mix of fundamentals that attracts FDI and test whether our results for exchange-rate volatility differ if we include in the sample only those countries with real GDP per capita above some threshold. The income threshold was chosen in a grid search to minimize the sum of squared residuals of the model $F D I_{i}=\left(X_{i j} B_{1, i j}\right)\left(I_{Y_{i}>\alpha}\right)+\left(X_{i j} B_{2, i j}\right)\left(I_{Y_{i}<\alpha}\right)+\varepsilon_{i}$, where FDI is country i's net FDI inflow as a share of its GDP, the $X_{i j}$ are the $\mathrm{j}$ control and volatility measures for country $\mathrm{i}$, and $\mathrm{I}$ is an indicator variable that takes on the value one if income is related to the threshold $\alpha$ as specified and is zero otherwise.

Regression (3) in Table 1 shows that the income truncation strengthens the results only slightly. For countries whose relative income position puts them in the group of mature markets, the correlation between volatility and FDI inflows remains positive and highly significant. At $\mathrm{z}=0.70$, the marginal effect of volatility is still 86 , with a standard error of 27.12. For countries whose relative income position places them in the emerging-market group, the correlation between volatility and FDI inflows is no longer significant even at the $90 \%$ confidence level. The marginal effect of volatility has fallen to 3.4986 , with a standard error of 3.51 .

Instead of truncating the sample by income, we also considered a procedure that allows the marginal effect of volatility on FDI to increase as the share of FDI in GDP increases. This procedure involved regressing a logarithmic transformation of the dependent variable on the 
controls and volatility. ${ }^{19}$ The results were essentially unchanged-volatility still had no significant effect on emerging markets' FDI inflows.

\section{6. $\underline{\text { Conclusion }}$}

Our theory suggests that volatility increases horizontal FDI but discourages vertical FDI. Assuming that emerging markets attract relatively more vertical FDI than do mature markets, we examined cross-country macroeconomic data over the 1980-99 period to see if we could uncover a differential impact of uncertainty on FDI to these two destinations. The results reported in the paper offer tentative support for the theory. While output volatility appears to have no noticeable effect on FDI inflows, real effective exchange-rate volatility has significant and differential effects on FDI into mature and emerging markets. The correlation between exchange-rate volatility and FDI inflows is positive and significant for relatively high-income countries. For lower-income countries, the correlation is not negative, but it is insignificantly different from zero. This finding is consistent with the view that greater uncertainty discourages vertical FDI and emerging markets attract a relatively greater share of vertical FDI.

We close the paper with an overview of some issues left for future research. In our model, a multinational adopted either a horizontal or vertical investment structure. Our model can be extended to consider multinationals with mixed patterns of vertical and horizontal FDI, where the initial choice of production structure is influenced by uncertainty. Our model can also be extended to account for the role of transportation costs and trade taxes in the determination of FDI patterns. In our model, we treat volatility as exogenous, so that any

19 The dependent variable becomes $\ln [\mathrm{y} /(1-\mathrm{y})]$, where y is the share of FDI inflows in GDP. The marginal effect of volatility on y is $\hat{\beta}_{i} y(1-y)$, where $\hat{\beta}_{i}$ is the estimated coefficient on volatility. In the sample, y ranges from zero to 0.10 (10 percent). 
implied causality runs from volatility to the FDI pattern. Yet in the long run, there may be a two-way interaction between volatility and economic structure. Volatility may not only affect the pattern of FDI, but the structure of FDI may, in turn, influence the amount of uncertainty. Modeling and testing such a two-way interaction is left for future research. Finally, our empirical tests focused on macroeconomic data. Further insight may be gained by using microeconomic data to measure the impact of uncertainty on horizontal and vertical FDI. 


\section{Appendix}

This appendix derives the main results of the paper.

\section{$\underline{\text { Demand for good Y }}$}

Applying (1), the demand for good $Y$ in each country is

$$
Y^{d}=\left[A / P_{y}\right]^{\eta} ; \quad \eta=\frac{1}{1-\delta}>1
$$

Hence, the total demand facing the multinational is $2 Y^{d}$.

\section{Equation (8)}

We calculate employment and profit for the multinational engaged in vertical FDI, assuming first that domestic and foreign productivity shocks are observed simultaneously. Applying (5) and (6), it follows that employment in the final-good sector (Y) and in the intermediate-good sector $(\mathrm{M})$ is:

$$
L_{Y}=\left[\frac{Y}{(1+\varepsilon) b}\right]^{2} ; \quad L_{M}^{*}=\left[\frac{Y}{\left(1+\varepsilon^{*}\right) b^{*}}\right]^{2}
$$

Monopoly profits are

$$
\Pi_{f}=2 Y^{d} P_{y}-L_{y}-w^{*} L_{M}^{*}-C_{f} .
$$

Substituting (A1)-(A2) into (A3), we find that

$$
\Pi_{f}=2 A Y^{\delta}-\left[\frac{2 Y}{(1+\varepsilon) b}\right]^{2}-w^{*}\left[\frac{2 Y}{\left(1+\varepsilon^{*}\right) b^{*}}\right]^{2}-C_{f}
$$

where $Y$ denotes the consumption level in $\mathrm{H}$. The first-order condition characterizing optimal output $(\widetilde{Y})$ and the resultant profits are 


$$
\tilde{Y}=\left[\frac{0.5 \delta A}{[(1+\varepsilon) b]^{-2}+w^{*}\left[\left(1+\varepsilon^{*}\right) b^{*}\right]^{-2}}\right]^{\frac{1}{2-\delta}} ; \Pi_{f}=2 A \tilde{Y}^{\delta}\{1-0.5 \delta\}-C_{f}
$$

The profits can be rewritten as

$$
\Pi_{f}=k_{f}\left\{\left[\theta_{f}\left\{(1+\varepsilon)^{-2}\right\}+\theta_{f}^{*}\left(1+\varepsilon^{*}\right)^{-2}\right]-\frac{\eta-1}{\eta+1}\right\}-C_{f}
$$

where

$$
k_{f}=(1-0.5 \delta) 2\left[A 2^{-\delta}\right]^{\frac{2 \eta}{\eta+1}}\left[\frac{\delta}{[b]^{-2}+w^{*}\left[b^{*}\right]^{2}}\right]^{\frac{\eta-1}{\eta+1}} ; \theta_{f}=\frac{[b]^{-2}}{[b]^{-2}+w^{*}\left[b^{*}\right]^{-2}} ; \quad \theta_{f}^{*}=\frac{w^{*}\left[b^{*}\right]^{-2}}{[b]^{-2}+w^{*}\left[b^{*}\right]^{-2}}
$$

Suppose now that the intermediate output is produced prior to the realization of the productivity shock in $\mathrm{H}$. In these circumstances, the optimal level of $Y$ is determined by maximizing expected profits:

$$
E\left[\Pi_{f}\right]=2 A Y^{\delta}-[Y / b]^{2} E\left[(1+\varepsilon)^{-2}\right]-w^{*}\left[\frac{Y}{\left(1+\varepsilon^{*}\right) b^{*}}\right]^{2}-C_{f}
$$

Output and profits are:

$$
\tilde{Y}=\left\{\frac{0.5 \delta A}{E\left[\{(1+\varepsilon) b\}^{-2}\right]+w^{*}\left[\left(1+\varepsilon^{*}\right) b^{*}\right]^{2}}\right\}^{\frac{1}{2-\delta}} ; \Pi_{f}=2 A \tilde{Y}^{\delta}\{1-0.5 \delta\}-C_{f} .
$$

\section{$\underline{\text { Equation (9) }}$}

Horizontal FDI implies that the multinational will produce the same good in multiple locations in order to minimize the cost of production: The multinational tries to minimize costs: 


$$
\begin{aligned}
& \operatorname{Min}\left\lfloor\left\{L_{Y}+w^{*} L_{Y}^{*}\right\}-\lambda\left\{(1+\varepsilon) a \sqrt{L_{Y}}+\left(1+\varepsilon^{*}\right) a^{*} \sqrt{L_{Y}^{*}}-\tilde{Y}\right\}\right\rfloor \\
& L_{Y} ; L_{Y}^{*}
\end{aligned}
$$

The firm allocates production to equate the marginal cost in the two locations:

$$
\frac{w^{*} \sqrt{L_{Y}^{*}}}{2\left(1+\varepsilon^{*}\right) a^{*}}=\frac{\sqrt{L_{Y}}}{2(1+\varepsilon) a}
$$

Consequently,

$$
\frac{L_{Y}}{L_{Y}^{*}}=\frac{[a(1+\varepsilon)]^{2}}{\left[a^{*}\left(1+\varepsilon^{*}\right) / w^{*}\right]^{2}}
$$

The multinational's profits are

$$
\Pi_{h}=2 A\left[\frac{(1+\varepsilon) a \sqrt{L_{Y}}+\left(1+\varepsilon^{*}\right) a^{*} \sqrt{L_{Y}^{*}}}{2}\right]^{\delta}-L_{Y}-w^{*} L_{Y}^{*}-C_{h}
$$

Applying (A8) to (A9) we find that

$$
\Pi_{h}=2^{1-\delta} A\left[L_{Y}\right]^{0.5 \delta}\left[(1+\varepsilon) a+\frac{\left\{\left(1+\varepsilon^{*}\right) a^{*}\right\}^{2}}{w^{*}(1+\varepsilon) a}\right]^{\delta}-L_{Y}\left[1+\frac{\left\{\left(1+\varepsilon^{*}\right) a^{*}\right\}^{2}}{w^{*}\left\{\left(1+\varepsilon^{*}\right) a^{*}\right\}^{2}}\right]-C_{h}
$$

The optimal employment allocation is obtained by maximizing (A10), implying that

$$
\tilde{L}_{Y}=\left\{\delta 2^{-\delta} A\right\}^{\frac{1}{1-0.5 \delta}}\left\{[(1+\varepsilon) a]^{2}+\frac{\left[\left(1+\varepsilon^{*}\right) a^{*}\right]^{2}}{w^{*}}\right\}^{-\frac{2(1-\delta)}{2-\delta}}[(1+\varepsilon) a]^{\frac{2(2-\delta)}{2-\delta}}
$$

Substituting (A11) into (A10) and collecting terms, we find that

$$
\Pi_{h}=k_{h}\left[\theta_{h}(1+\varepsilon)^{2}+\theta_{h}^{*}\left(1+\varepsilon^{*}\right)^{2}\right]^{\frac{\eta-1}{\eta+1}}-C_{h}
$$


where

$$
k_{h}=(1-0.5 \delta) 2\left[A 2^{-\delta}\right]^{\frac{2 \eta}{\eta+1}}\left[\delta\left\{a^{2}+\frac{\left[a^{*}\right]^{2}}{w^{*}}\right\}\right]^{\frac{\eta-1}{\eta+1}} ; \theta_{h}=\frac{a^{2} w^{*}}{a^{2} w^{*}+\left[a^{*}\right]^{2}} ; \theta_{h}^{*}=\frac{\left[a^{*}\right]^{2}}{a^{2} w^{*}+\left[a^{*}\right]^{2}}
$$

\section{$\underline{\text { Proposition } 1}$}

We derive proposition 1 by examining the concavity properties of (A6) and (A12) around $\varepsilon=\varepsilon^{*}=0$. Consider the function

$$
Z=\left[\theta(1+\varepsilon)^{\alpha}+\theta^{*}\left(1+\varepsilon^{*}\right)^{\alpha}\right]^{\beta}
$$

where $\theta^{*}+\theta=1$. Fragmentation (vertical FDI) corresponds to $\alpha=-2 ;-1<\beta<0$. [See (A6)]. Diversification (horizontal FDI) corresponds to $\alpha=2 ; 0<\beta<1$. [See (A12)].

It is easy to confirm that

$$
\begin{gathered}
\left.\operatorname{sign} \frac{d^{2} Z}{d \varepsilon^{2}}\right|_{\varepsilon=0 ; e^{*}=0}=\operatorname{sign}\{\alpha \beta[(\beta-1) \theta \alpha+(\alpha-1)]\} . \\
\left.\operatorname{sign} \frac{d^{2} Z}{d \varepsilon^{2}}\right|_{\alpha=-2 ;-1<\beta<0 ; \varepsilon=0 ; \varepsilon^{*}=0}=\operatorname{sign}[-2(\beta-1) \theta-3]<0
\end{gathered}
$$

Hence,

$$
\left.\operatorname{sign} \frac{d^{2} Z}{d \varepsilon^{2}}\right|_{\alpha=2 ; 0<\beta<1 ; \varepsilon=0 ; \varepsilon^{*}=0}=\operatorname{sign}[2(\beta-1) \theta+1]>0
$$

Identical results hold for $\left.\operatorname{sign} \frac{d^{2} Z}{d\left(\varepsilon^{*}\right)^{2}}\right|_{\varepsilon=0 ; \varepsilon^{*}=0}$.

\section{$\underline{\text { Equation (11) }}$}

Applying (8) to the case where $\varepsilon=\varepsilon^{*}=0$, and recalling that the opportunity cost of labor is constant, we infer that the surplus associated with vertical FDI is $k_{f}-C_{f}$, and that 
in the absence of agreement, the surplus would be $-C_{f}$. Hence, the net surplus associated with agreement is $k_{f}$. The bargaining outcome would allocate a fraction $\phi$ of the surplus to the multinational [and a fraction $1-\phi$ to country F]. The equilibrium outcome is determined by maximizing the corresponding Nash product:

$$
\begin{aligned}
& \operatorname{MAX}\left[\phi k_{f}+I_{0}-C_{f}-\left(I_{0}-C_{f}\right)\right]\left[U_{0}+(1-\phi) k_{f}-U_{0}\right] \\
& \phi
\end{aligned}
$$

where $I_{o}$ is the outside income of the multinational [i.e., the income not affected by the production decisions regarding good $Y$ ], and $U_{o}$ is the utility of the host country in the absence of agreement. Equation (A15) is equivalent to $\operatorname{MAX}\{\phi(1-\phi)\}$, implying that $\phi=0.5$. Consequently, the multinational's net profits in the bargaining regime are

$$
0.5 k_{f}-C_{f} \text {. }
$$

\section{Equation (12)}

Applying (A12) in the case where $\varepsilon=\varepsilon^{*}=0$, and recalling that the labor's opportunity cost is constant, we infer that the profit associated with undisturbed production under horizontal FDI is:

$$
\Pi_{h}=k_{h}-C_{h}
$$

In the absence of agreement, the multinational would produce only in one plant. The resultant profit is found by evaluating (A12) for the case where $a^{*}=0$, resulting in

$$
\Pi_{h}=k_{h}^{0}\left[\theta_{h}\right]^{\frac{\eta-1}{\eta+1}}-C_{h}
$$

where $k_{h}^{0}=(1-0.5 \delta) 2\left[A 2^{-\delta}\right]^{\frac{2 \eta}{\eta+1}}\left[\delta a^{2}\right]^{\frac{\eta-1}{\eta+1}}$

Hence, the agreement would increase profits by 


$$
\Delta \Pi_{h}=(1-0.5 \delta) 2\left[A 2^{-\delta}\right]^{\frac{2 \eta}{\eta+1}}\left[\delta\left(\left\{a^{2}+\frac{\left[a^{*}\right]^{2}}{w^{*}}\right\}^{\frac{\eta-1}{\eta+1}}-\left\{a^{2} \theta_{h}\right\}^{\frac{\eta-1}{\eta+1}}\right)\right]
$$

The bargaining outcome is the solution to

$$
\begin{aligned}
& M A X\left[\phi \Delta \Pi_{h}+I_{0}-C_{f}-\left(I_{0}-C_{f}\right)\right]\left[U_{0}+(1-\phi) \Delta \Pi_{h}-U_{0}\right] \\
& \phi
\end{aligned}
$$

Equation (A20) is equivalent to $\operatorname{MAX}\{\phi(1-\phi)\}$, implying that $\phi=0.5$. The multinational's net profits in the bargaining regime are

$$
0.5\left\{k_{h}+k_{h}^{0}\left[\theta_{h}\right]^{\frac{\eta-1}{\eta+1}}\right\}-C_{h}
$$

Consequently, the switch to the bargaining regime reduces the multinational's gross profits at a rate of

$$
\left[k_{h}-0.5\left\{k_{h}+k_{h}^{0}\left[\theta_{h}\right]^{\frac{\eta-1}{\eta+1}}\right\}\right] / k_{h}=0.5\left\{1-\frac{k_{h}^{0}}{k_{h}}\left[\theta_{h}\right]^{\frac{\eta-1}{\eta+1}}\right\}=0.5\left\{1-\left[\theta_{h}\right]^{2 \frac{\eta-1}{\eta+1}}\right\}
$$




\section{3-Country Sample (mature markets underlined, emerging markets in italics)}

Argentina, Australia, Austria, Belgium, Brazil, Canada, Chile, Colombia, Denmark, Finland, France, Greece, Hungary, Iceland, Indonesia, Ireland, Italy, Japan, Korea (Rep), Malaysia, Mexico, Netherlands, New Zealand, Norway, Peru, Philippines, Portugal, Singapore, Spain, Sweden, Switzerland, Thailand, Turkey, United Kingdom, United States, Bahamas, Bangladesh, Barbados, Belize, Benin, Bolivia, Botswana, Bulgaria, Berkina Faso, Burundi, Cameroon, Central African Republic, China, Congo (Rep), Costa Rica, Cote d'Ivoire, Cyprus, Dominican Republic, Ecuador, Egypt, El Salvador, Fiji, Gabon, Gambia, Ghana, Guatemala, Guinea-Bissau, Guyana, Haiti, Honduras, India, Iran, Israel, Jamaica, Jordan, Kenya, Lesotho, Malawi, Mali, Malta, Mauritania, Mauritius, Morocco, Mozambique, Nepal, Nicaragua, Niger, Nigeria, Oman, Pakistan, Panama, Papua-New Guinea, Paraguay, Romania, Rwanda, Senegal, Sierra Leone, Solomon Islands, Sri Lanka, Swaziland, Syria, Togo, Trinidad and Tobago, Tunisia, Uruguay, Venezuela, Zambia, Zimbabwe. 


\section{References}

Aizenman, J. 1994, "Monetary and real shocks, productive capacity and exchange rate regimes," Economica, November, 407-34.

Aizenman, J. and N. P. Marion, 1993, "Policy Uncertainty, Persistence and Growth," Review of International Economics; 1(2), June, 145-63. , 1999, "Volatility and Investment: Interpreting Evidence from Developing Countries," Economica 66, 157-79.

Blonigen, Bruce. 1997, "Firm-Specific Assets and the Link Between Exchange Rates and Foreign Direct Investment," American Economic Review 87, June, 447-466.

Brainard, S. L., 1997, “An Empirical Assessment of the Proximity-Concentration Tradeoff between Multinational Sales and Trade," American Economic Review 87, 520-544.

Carr, David L., James R. Markusen and Keith E. Maskus, 2001, “Estimating KnowledgeCapital Model of the Multinational Enterprise," American Economic Review 91, No.3 (June), 693-708.

Dunning, J. H., 1993, Multinational Enterprises and the Global Economy, Addison Wesley.

Feenstra, Robert C. and Gordon H. Hanson, 1997, "Foreign Direct Investment and Relative Wages: Evidence from Mexico's Maquiladoras," Journal of International Economics, Vol. 42: 371-394.

Froot, Ken and J. Stein, 1991, "Exchange Rates and Foreign Direct Investment: An Imperfect Capital Markets Approach," Quarterly Journal of Economics 106, 11911217. 
Goldberg, L. S. and Kolstad, C. D., 1995, “Foreign Direct Investment, Exchange Rate Variability and Demand Uncertainty," International Economic Review, vol 36, no.4, pp.855-873.

Grossman G. M. and E. Helpman, 2001, "International Outsourcing," presented at the ITI NBER Summer Institute, Cambridge, MA.

Hanson Gordon H., Raymond J. Mataloni, Jr., Matthew J. Slaughter, 2001, ” Expansion Strategies of U.S. Multinational Firms,” NBER Working Paper No. W8433.

Hausmann, Ricardo and Michael Gavin, 1995, “Overcoming Volatility,” Part II of Economic and Social Progress in Latin America, Inter-American Development Bank.

Helpman, Elhanan. 1984, “A Simple Theory of Trade with Multinational Corporations,” Journal of Political Economy 92, 451-471. and Paul Krugman, 1985, Market Structure and International Trade, MIT Press.

International Finance Corporation, 1999, Emerging Stock Markets Review, Washington, D.C.: International Finance Corporation.

Klein, Michael and Eric Rosengren, 1994, “The Real Exchange Rate and Foreign Direct Investment in the United States: Relative Wealth vs. Relative Wage Effects," Journal of International Economics 36, 373-389.

Levine, Ross and D. Renelt, 1992, “A Sensitivity Analysis of Cross-Country Growth Regressions," American Economic Review 82, 942-63.

Markusen J. R. and K. E. Maskus, 2001, “General-Equilibrium Approaches to the Multinational Firm: A Review of Theory and Evidence,” NBER WP No. 8334. Pagan, Adrian, 1984, "Econometric Issues in the Analysis of Regressions with Generalized Regressors," International Economic Review 25, 221-48. 
World Bank, 2000, World Development Indicators, CD.

Ramey, G. and V. A. Ramey, 1995, "Cross-Country Evidence on the Link between Volatility and Growth," American Economic Review; 85(5), December, 1138-51.

Smarzynska, Beata and Shang-Jin Wei, 2000, "Corruption and Composition of Foreign Direct Investment: Firm-Level Evidence,” NBER Working Paper No. 7969.

Spiegel, M. Mark, 1994, “Sovereign Risk Exposure With Potential Liquidation: The Performance of Alternative Forms of Financing," Journal of International Money and Finance, 400-414.

Wei, Shang-Jin, 1997, "Why is Corruption So Much More Taxing Than Tax? Arbitrariness Kills," NBER Working Paper No. 6255. 


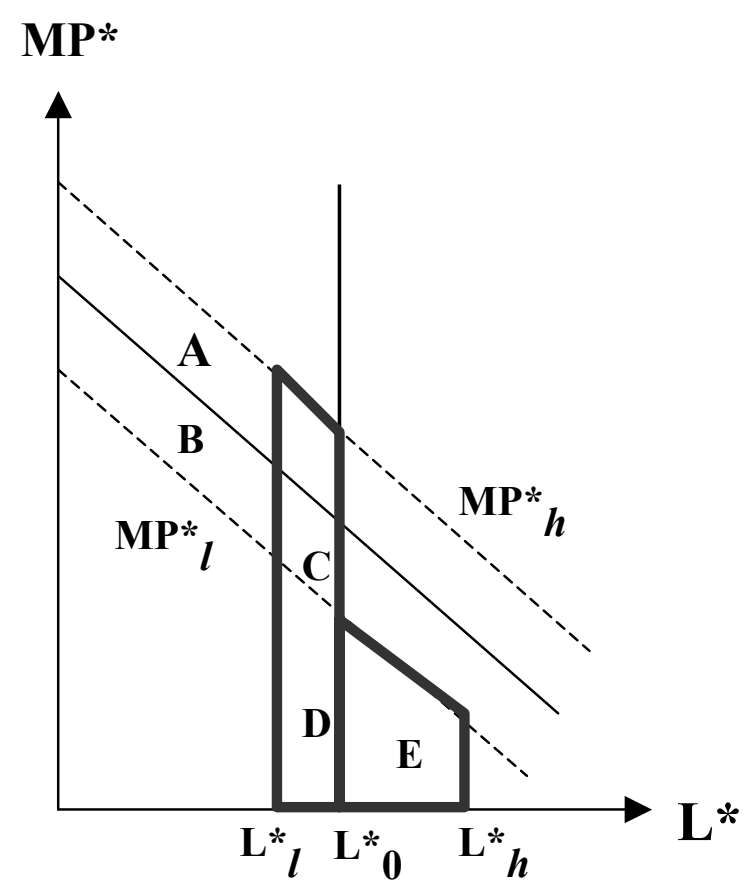

(1a)

\section{MP*}

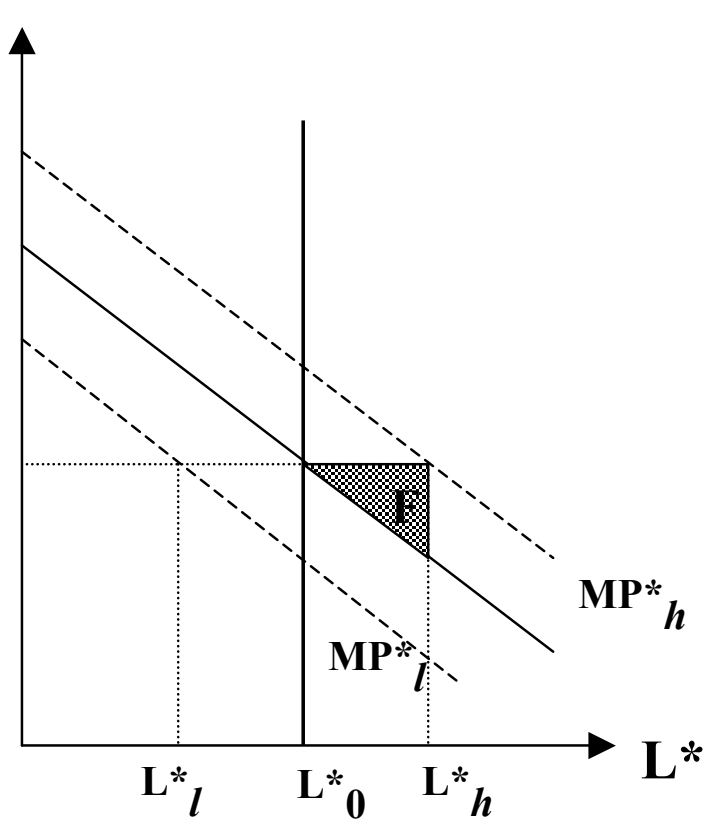

(1b)

\section{Figure 1}

\section{Volatility and the marginal product of labor}

The dotted curves trace the marginal product of labor in the plant in country $\mathrm{F}$ when the

foreign productivity fluctuates between $\left(\varepsilon_{0}^{*} ;-\varepsilon_{0}^{*}\right)$ with equal probabilities. Panel (1a)

corresponds to the marginal product of labor when the plant is part of a vertical production structure. Panel (1b) corresponds to the marginal product of labor when the plant is part of a horizontal pattern. 


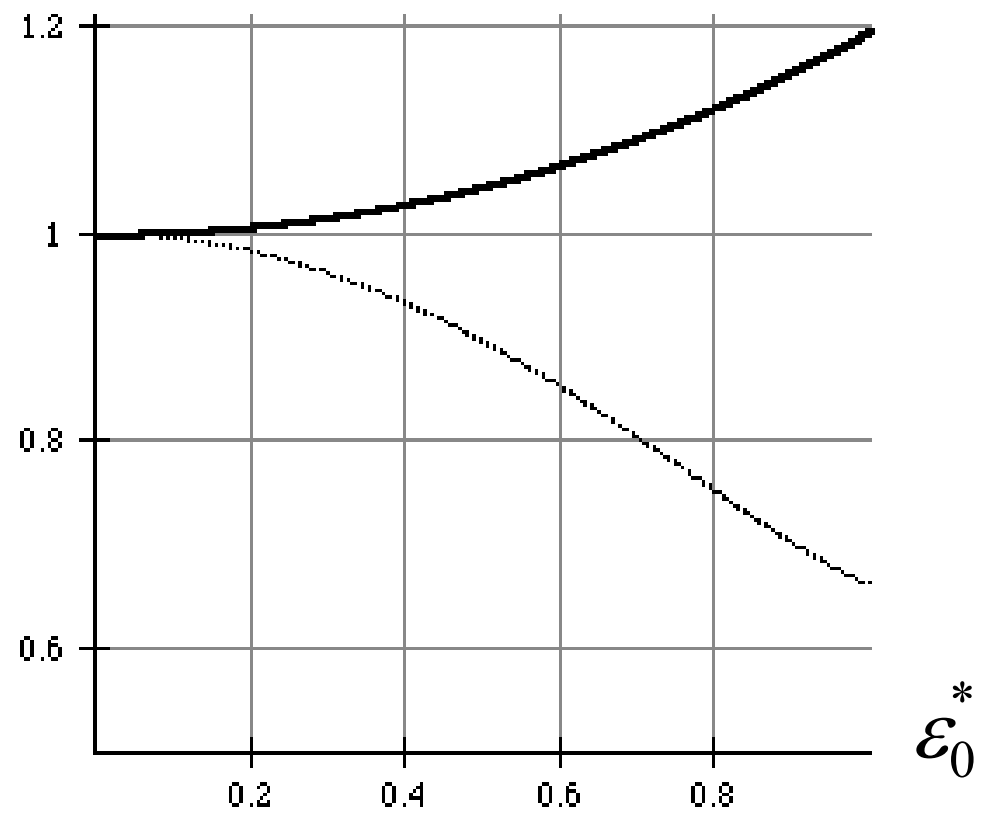

Figure 2

\section{Profit with foreign productivity shocks}

The curves trace the relationship between expected gross profits [before covering the set-up cost] and the foreign productivity shock, $\varepsilon_{0}^{*}$, for the case where foreign productivity fluctuates between $\left(\varepsilon_{0}^{*} ;-\varepsilon_{0}^{*}\right)$, with equal probabilities. Gross profits in the absence of uncertainty are normalized to 1 and the price-elasticity of demand for good $\mathrm{Y}$ is $\eta=4$. The bold (dotted) line corresponds to horizontal (vertical) production. 


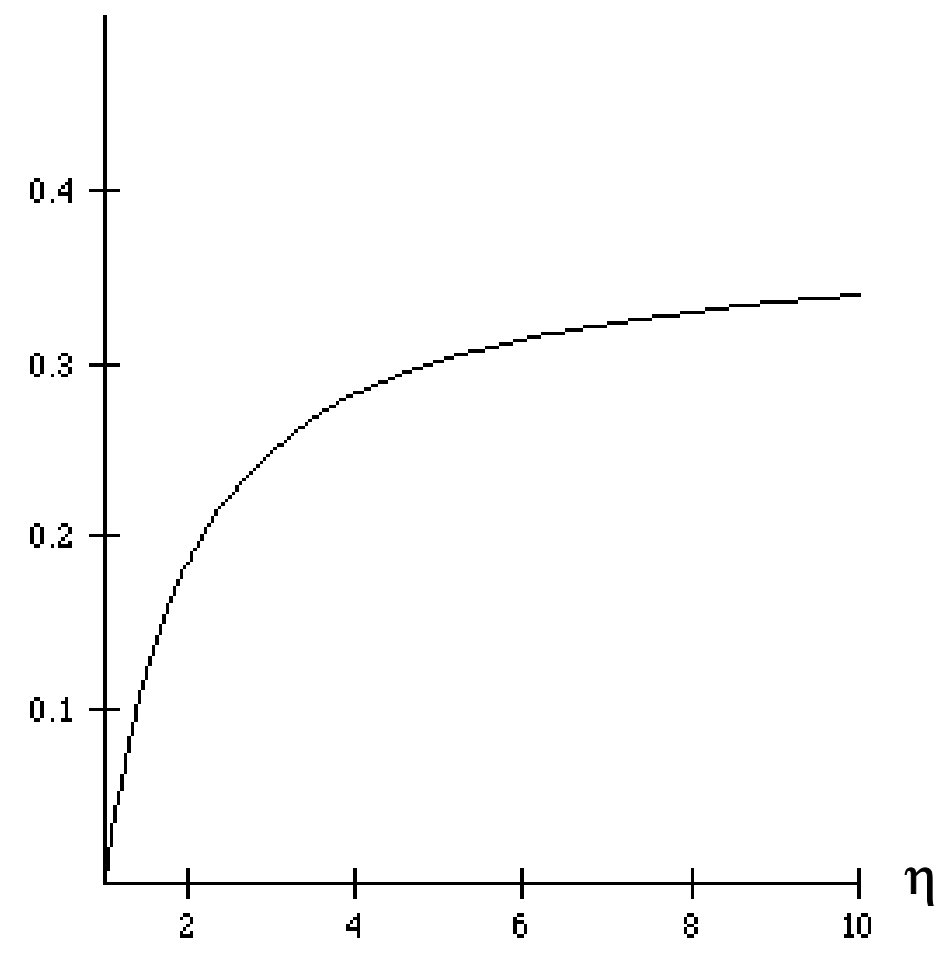

Figure 3

\section{Bargaining outcomes and the elasticity of demand}

The curve plots the relationship between the percentage loss of gross profits and the elasticity of demand when the multinational with horizontal FDI is forced into the bargaining outcome. It is assumed that production shares in the two countries are equal $\left(\theta_{d}=\theta_{d}^{*}\right)$ 
Marginal Effect of Volatility on FDI Inflows

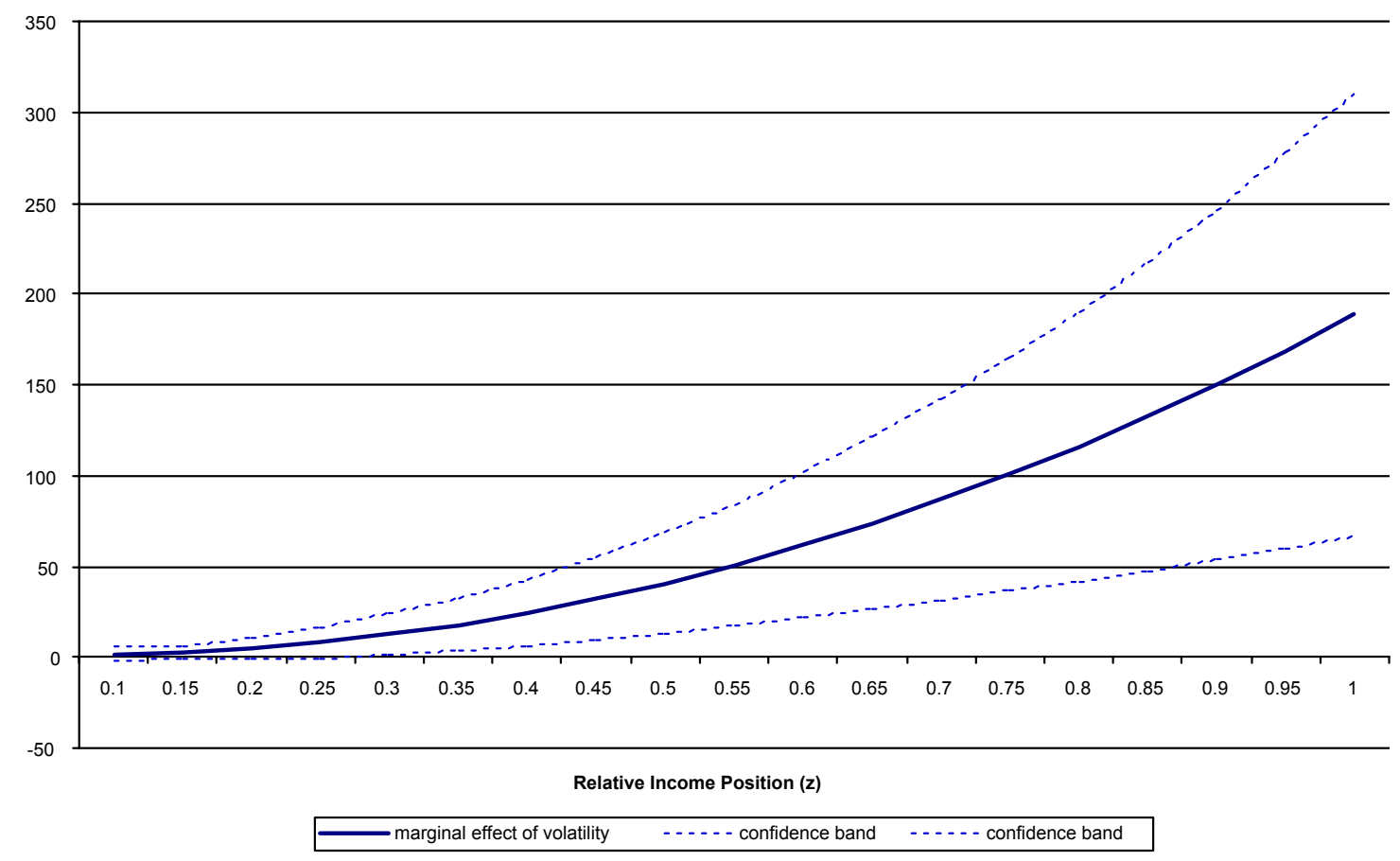

Figure 4: Marginal Effect of Volatility For Given Relative Incomes 
Table 1: Relationship Between FDI Inflows and Volatility

\begin{tabular}{|c|c|c|c|}
\hline Variable & $\begin{array}{l}\text { (1) } \\
\text { output volatility }\end{array}$ & $\begin{array}{l}\text { (2) } \\
\text { exchange-rat }\end{array}$ & $\begin{array}{l}\text { (3) } \\
\text { ility }\end{array}$ \\
\hline $\mathrm{n}$ & 103 & 103 & 85 \\
\hline $\mathrm{c}$ & $\begin{array}{l}-19.7457^{*} \\
(11.0496)\end{array}$ & $\begin{array}{l}-25.1468^{* *} \\
(8.2020)\end{array}$ & $\begin{array}{l}-48.4643^{* *} \\
(21.2837)\end{array}$ \\
\hline $\begin{array}{l}\text { log real per cap GDP } \\
\text { in } 1980\end{array}$ & $\begin{array}{l}5.1229^{*} \\
(3.0453)\end{array}$ & $\begin{array}{l}6.9021 * * \\
(2.1505)\end{array}$ & $\begin{array}{l}12.4280^{* *} \\
(5.3392)\end{array}$ \\
\hline $\begin{array}{l}\text { log real per cap GDP } \\
\text { in } 1980, \text { squared }\end{array}$ & $\begin{array}{l}-0.3104 \\
(0.2068)\end{array}$ & $\begin{array}{l}-0.4538^{* *} \\
(0.1393)\end{array}$ & $\begin{array}{l}-0.7766^{* *} \\
(0.3284)\end{array}$ \\
\hline $\begin{array}{l}\text { sec school enrollment } \\
\text { in } 1980\end{array}$ & $\begin{array}{l}-0.0169 * * \\
(0.0083)\end{array}$ & $\begin{array}{l}-0.0161 * * \\
(0.0080)\end{array}$ & $\begin{array}{l}-0.0164 * * \\
(0.0082)\end{array}$ \\
\hline $\begin{array}{l}\text { pop growth } \\
\text { in } 1980\end{array}$ & $\begin{array}{l}-0.3940 * * \\
(0.1971)\end{array}$ & $\begin{array}{l}-0.4488^{* *} \\
(0.1894)\end{array}$ & $\begin{array}{l}-0.4204 * * \\
(0.1974)\end{array}$ \\
\hline avg. trade share & $\begin{array}{l}0.0263 * * \\
(0.0041)\end{array}$ & $\begin{array}{l}0.0299 * * \\
(0.0042)\end{array}$ & $\begin{array}{l}0.0282 * * \\
(0.0040)\end{array}$ \\
\hline volatility & $\begin{array}{l}6.8662 \\
(6.3166)\end{array}$ & $\begin{array}{l}2.7213 \\
(5.3286)\end{array}$ & $\begin{array}{l}6.4621 \\
(8.3146)\end{array}$ \\
\hline volatility*z & $\begin{array}{l}-31.8883 \\
(58.1120)\end{array}$ & $\begin{array}{l}-33.4346 \\
(46.5635)\end{array}$ & $\begin{array}{l}-68.1363 \\
(71.1444)\end{array}$ \\
\hline volatility*z ${ }^{2}$ & $\begin{array}{l}76.7687 \\
(108.4520)\end{array}$ & $\begin{array}{l}219.0780^{* *} \\
(85.4327)\end{array}$ & $\begin{array}{l}259.9990^{* *} \\
(114.8280)\end{array}$ \\
\hline $\bar{R}^{2}$ & 0.50 & 0.55 & 0.57 \\
\hline
\end{tabular}

Notes: Dependent variable is the average share of net FDI inflows in GDP over the 1980-99 period. The variable $\mathrm{z}$ measures the country's real income per capita relative to the U.S. Equation (1) looks at output volatility. Equations (2)-(3) focus on volatility of the real effective exchange rate. Regression (3) truncates the sample by real GDP per capita. $* *(*)$ signifies significance at the $95 \%(90 \%)$ confidence interval. Numbers in parentheses are heteroscedastic-consistent standard errors.

Sources: Real effective exchange rate data from the IMF's Information Notice System. Real GDP per capita data from the Penn World Tables. All other data from the World Bank's World Development Indicators (2001 CD). Countries listed in the appendix. 